\title{
The Green Party: ‘Green Surge’ or Work in
}

\section{Progress?}

Le parti vert: 'Poussée verte' ou travaux en cours?

\section{Brendan Prendiville}

\section{OpenEdition}

1 Journals

Electronic version

URL: https://journals.openedition.org/rfcb/618

DOI: $10.4000 / \mathrm{rfcb} .618$

ISSN: 2429-4373

\section{Publisher}

CRECIB - Centre de recherche et d'études en civilisation britannique

\section{Electronic reference}

Brendan Prendiville, "The Green Party: 'Green Surge' or Work in Progress?", Revue Française de Civilisation Britannique [Online], XX-3 | 2015, Online since 01 décembre 2015, connection on 28 juin 2022. URL: http://journals.openedition.org/rfcb/618 ; DOI: https://doi.org/10.4000/rfcb.618

This text was automatically generated on 29 September 2020

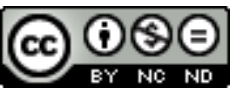

Revue française de civilisation britannique est mis à disposition selon les termes de la licence Creative Commons Attribution - Pas d'Utilisation Commerciale - Pas de Modification 4.0 International. 


\title{
The Green Party: ‘Green Surge' or Work in Progress?
}

\author{
Le parti vert: 'Poussée verte' ou travaux en cours?
}

\author{
Brendan Prendiville
}

The Green Party ${ }^{1}$ first stood for elections in 1974 and for a long time was remarkable only for its spectacular lack of success. Up to 2001, it systematically lost all its deposits and without the help of Edward Goldsmith, it would, no doubt, have disappeared from the political stage before M. Thatcher came to power in $1979 .{ }^{2}$ It had to wait until the 2005 general election to poll more than $1 \%$ of the national vote $(1.04 \%)$ and it was only five years later that it won its first parliamentary seat, when Caroline Lucas wrested the Brighton Pavilion constituency from the Labour Party. ${ }^{3}$ In national, parliamentary elections therefore, the Greens have come a long way.

In the recent 2015 elections, the Green Party had, overall, a good election campaign. Apart from what the media termed a 'car crash' interview in which Natalie Bennett, the Green leader, was unable to answer a question on the costing of Green housing policy ${ }^{4}$, a certain number of policy proposals considered to be beyond the political pale ${ }^{5}$ and a majority Green council in Brighton under fire for its low recycling rate, the media interest in the Greens was high, and relatively favourable. Caroline Lucas received glowing praise for her work in Parliament, the political visibility of the Green Party shot up (which is one of the principal aims of a minority party in a non-majority electoral system) and more media light was shed on the work of local greens around the country, in councils other than Brighton.

This article has been entitled The Green Party: 'Green surge' or Work in Progress?, that is, did this green surge really take place or was it simply the media building up interest in a campaign which was often lacking in interest? And was this election a non-event for the Greens who are still as far away from institutional political power as ever or can they take some positives away from it? We will firstly analyse the parameters of the green surge in terms of its internal and external dimensions. That is to say, certain factors which contributed to the green surge were partly of the Greens' making (membership, candidates) while others were largely out of their control (polls, TV debate). Secondly, we 
will consider the politics of this surge by analysing two aspects of the campaign: the threat that the Greens represented for the Labour Party in particular and the reasons why more voters were saying they would vote Green than in previous general elections. The final part will be taken up by a discussion of the results and how the campaign may have helped the Greens to move forward.

\section{Green surge}

The so-called green surge of the 2015 British general elections was, in fact, not the first of its kind. Following the European elections of 1989 in which the Greens received almost $15 \%$ of the vote, its membership rose to 18,523 in January 1990, having stood at 11,000 the previous year. ${ }^{6}$ Four years later (1993), it was clear that this surge was a flash in the pan as membership had dropped to 5,500 and the Greens had received $0.5 \%$ of the national vote in the 1992 general elections. How does the 2015 green surge compare?

The first, internal factor of this surge that became clear some time before the electoral campaign started was the rise in the numbers of people joining the two British Green Parties. By the end of 2014, membership of the Green Party of England and Wales (GPEW) had more than doubled and five months later it had quadrupled from its original figure of 15,000 in January 2014 to over 66,000 in May 2015 (Chart 1). Similarly, this rise was paralleled by new members joining the Scottish Greens, both before and following the Scottish referendum. From 2,000 members in January 2014, the Scottish Greens grew to 9,000 in June 2015.

Chart 1: Political Party Membership in Britain (2010-2015) ${ }^{7}$

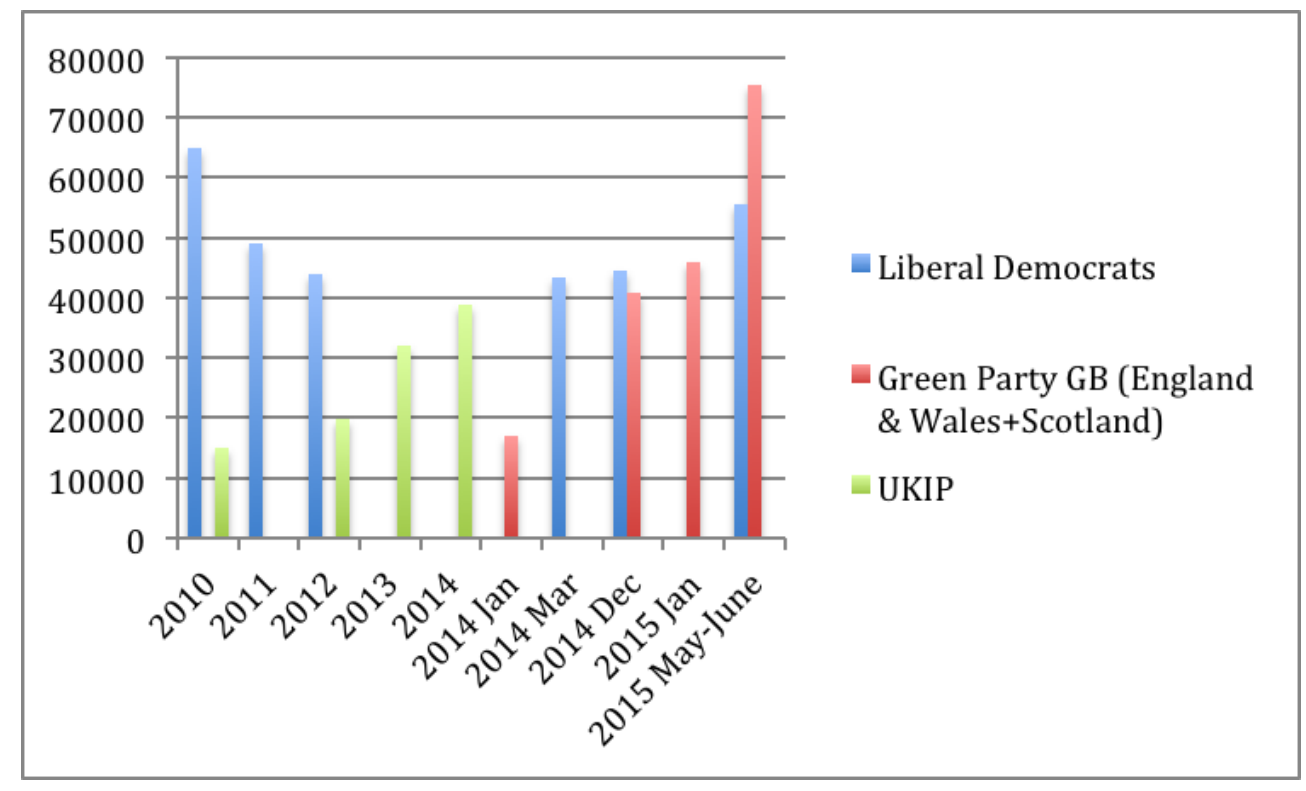

Towards the end of 2014, the term green surge acquired a hashtag and became a media event in itself with figures being published on a regular basis, highlighting how the traditional political landscape was changing even before votes had been cast. There was particular interest when the membership of the two Green parties overtook that of the Liberal Democrats and of UKIP in January 2015, thereby becoming the third largest political party grouping in Britain with 75,557 members. ${ }^{8}$ Time will tell how solidly grounded this membership rise is but given that the rise continued even after the votes 
were counted, ${ }^{9}$ Green activists north and south of the Scottish border were no doubt feeling somewhat more confident than their counterparts in the aftermath of the 1989 European elections.

The second internal factor concerned the number of candidates the Greens put up for election in 2015. Since their inception, the Greens, as any minority party under the 'first past the post' electoral system, have been hampered by their inability to put up the number of candidates they would have wished. The electoral deposit - at present $£ 500$ reimbursed with a minimum vote of $5 \%$ - has always been a sizeable financial barrier to Green progress. Although the Greens today are in a better financial situation (Table 1), especially since the growth in membership, the disparity between the minority GPEW and the institutional parties remains sizeable (Table 2)

Table 1: Green Party (GPEW) Funding (2010-2014) ${ }^{10}$

\begin{tabular}{|l|l|l|l|}
\hline & Donations (£) & Public Funds (£) & Total (£) \\
\hline 2014 & 648,660 & 63,356 & 712,016 \\
\hline 2013 & 190,337 & 54,886 & 245,223 \\
\hline 2012 & 254,483 & 59,896 & 314,379 \\
\hline 2011 & 158,830 & 24,858 & 183,688 \\
\hline 2010 & 146,832 & 0 & 146,832 \\
\hline
\end{tabular}

Table 2: Party funding (UK 2014) ${ }^{11}$

\begin{tabular}{|l|l|l|l|}
\hline & Donations $(£)$ & Public Funds $(£)$ & Total $(£)$ \\
\hline Conservative & $28,950,917$ & 152,663 & $29,103,580$ \\
\hline Labour & $18,523,701$ & $7,541,143$ & $26,064,844$ \\
\hline Lib Dems & $8,096,689$ & 492,198 & $8,588,887$ \\
\hline SNP & $3,772,594$ & 352,854 & $4,125,448$ \\
\hline UKIP & $3,500,570$ & - & $3,500,570$ \\
\hline Green Party & 648,660 & 63,356 & 712,016 \\
\hline
\end{tabular}

This healthier financial situation explains the Greens' decision to put up 537 candidates in England and Wales, that is, in the vast majority of the available constituencies. ${ }^{12} \mathrm{~A}$ look at the evolution of candidate presentation rates over the years (Chart 2) gives an indication of the confidence within the Green party going into this election. 


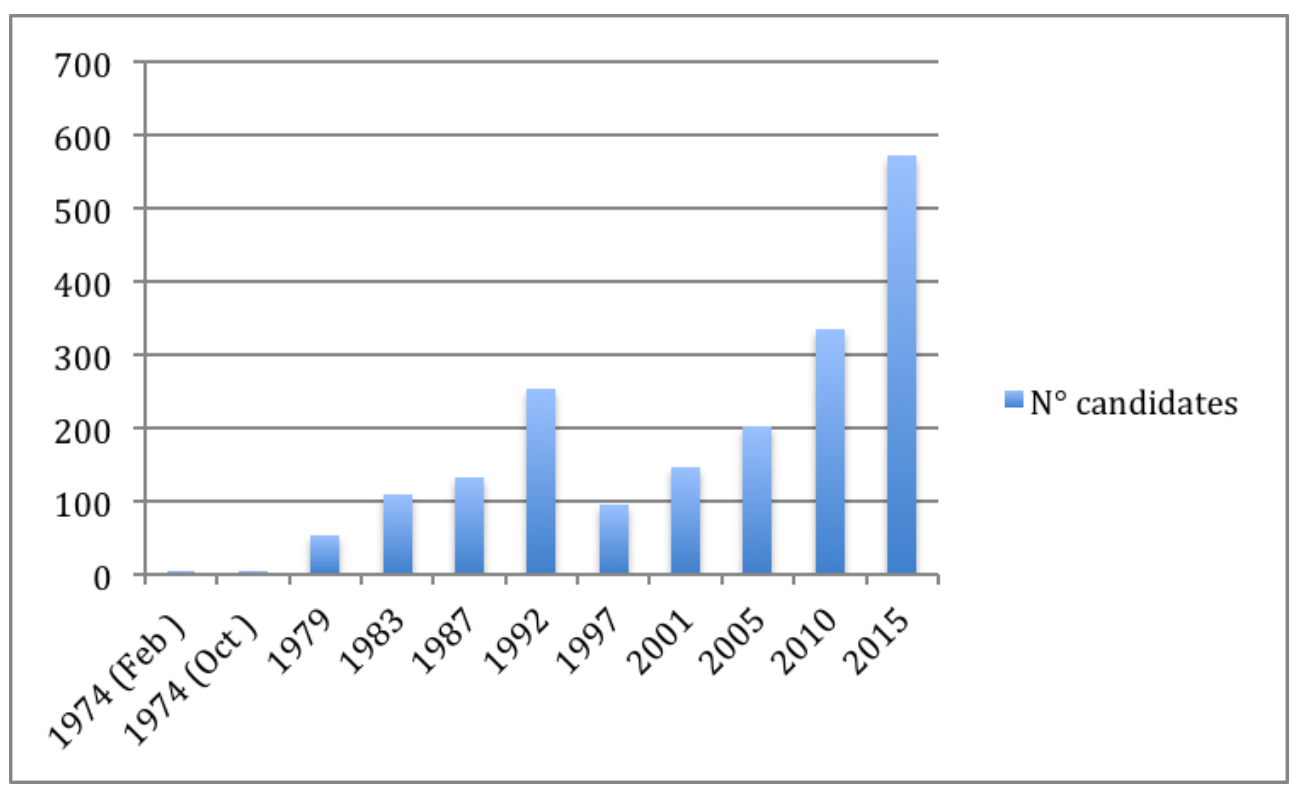

The first external factor was the importance of favourable polling for the Greens in the months leading up to the election. Already in 2014, the polls were looking good (Chart 3) even if the rise was not as smooth as this chart suggests.

Chart 3: Opinion Poll YouGov (Green Party) ${ }^{14}$

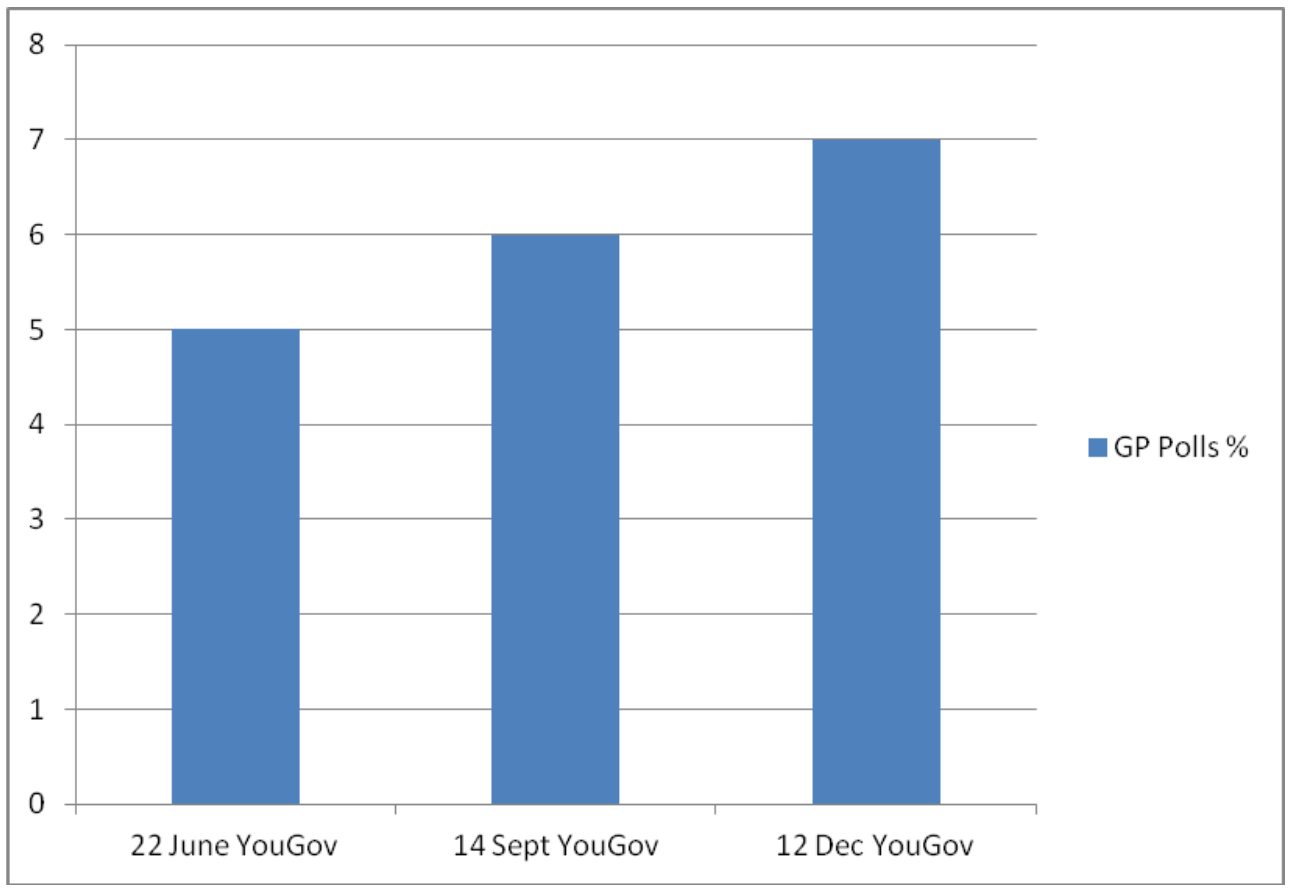

Given the past electoral history of the Greens, to be polling at 7\%, four months before a general election was very encouraging and it got even better in January 2015 when an Ashcroft poll put them at $11 \% \cdot{ }^{15}$ A large part of this polling surge was due to the support they received from young people. During the course of 2014, the percentage of young people between 18-24 supporting the Greens went from 7\% in January to $19 \%$ in December 
(Graph 1). However, encouraging as this was for the Greens, turn out rates of voting for this cohort are, traditionally, also the lowest.

Graph 1 : Youth support for the Greens (2014) ${ }^{16}$

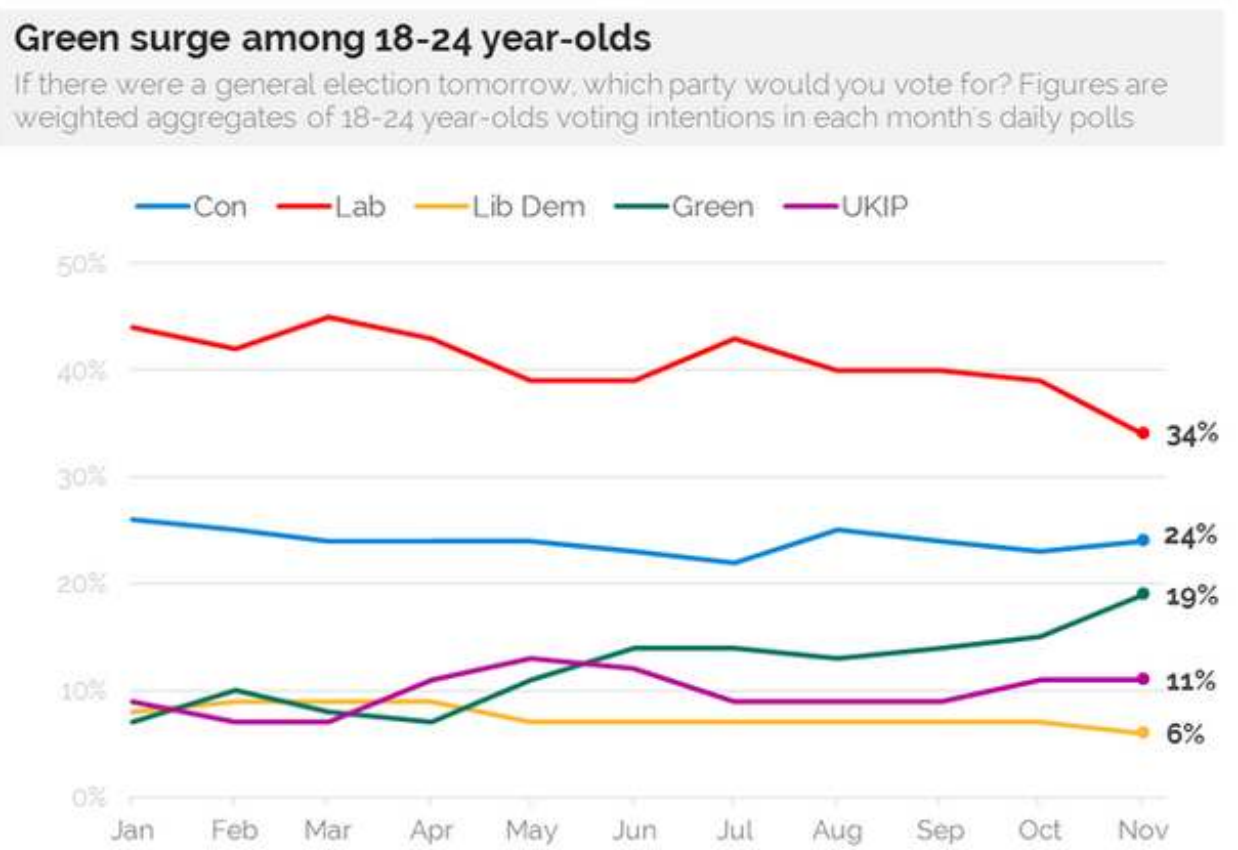

The second external factor was the question of the TV election debates from which the Greens were initially excluded before the broadcasters had a change of mind and, under pressure from the public, included them. The debates became an issue on $13^{\text {th }}$ October when the main broadcasters released plans to hold several leaders' debates with the main party leaders as well as Nicolas Farage, leader of UKIP. There were no plans however for the Green leader, Natalie Bennett, to participate in any of them. This produced much anger from the Green Party as well as threats to take legal advice on this exclusion. It also, more importantly as it transpired, produced a citizen reaction when an online petition was created to protest against this exclusion. At the beginning of election year ( 7 th January 2015), almost 300,000 people had signed this petition amidst a national campaign to support the Greens' presence in the leaders' debates. However, the following day ( $8^{\text {th }}$ January), Ofcom ${ }^{17}$ judged that the Green Party would not be included in the live TV debates when it decided not to give it "Major Party Status". ${ }^{18}$ Disappointing as this was, the campaign to include the Greens in these debates continued buoyantly into the New Year with one of its highlights being the launch of a poster campaign on $19^{\text {th }}$ January around a picture of Caroline Lucas and Natalie Bennett standing next to the caption "What are you afraid of, boys?" (Image 1) 


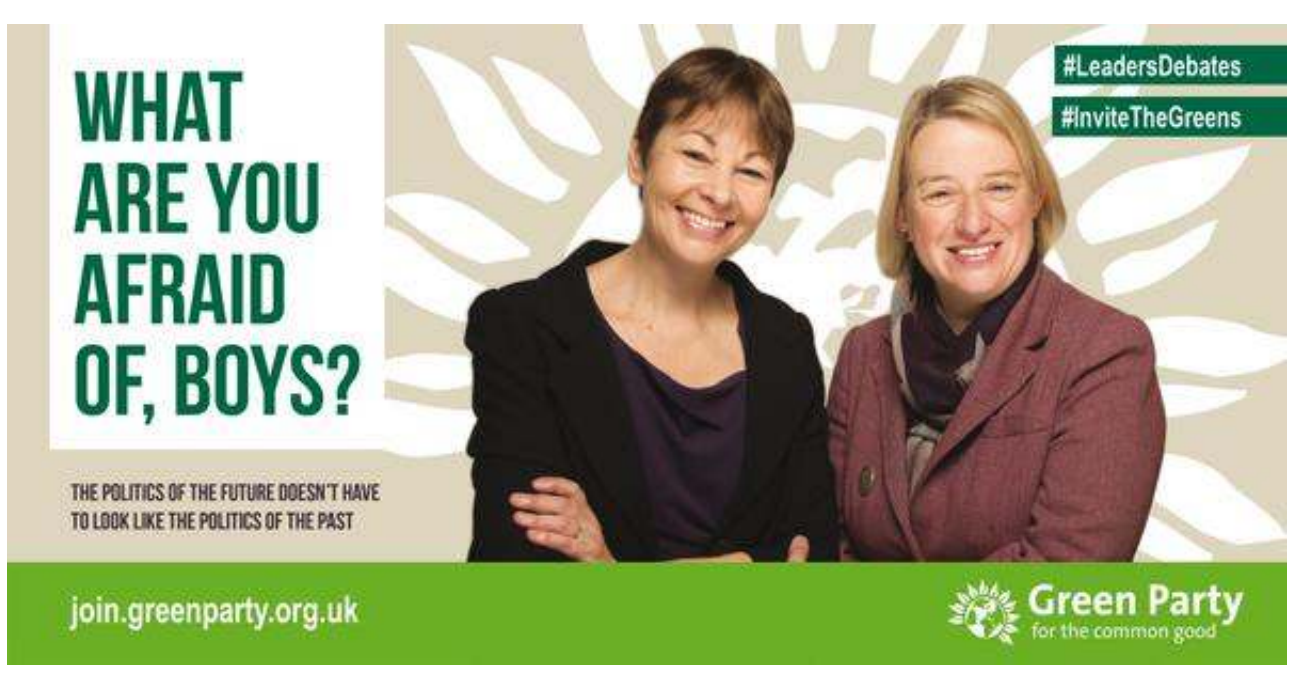

On the $22^{\text {nd }}$ January, the main broadcasters put an end to this campaign by announcing that the Greens would indeed be invited, along with the Welsh (Plaid Cymru) and the Scottish (SNP) nationalist parties, to take part in two of the four TV election debates. This was seen as a victory for the Greens and, with hindsight, can be explained by two factors. The first factor was the success of the aforementioned petition followed up by the equally successful poster campaign which had a series of repercussions. This poster was clearly critical of male domination of the three major parties but it was also seen, and indeed explained by Natalie Bennett on different occasions, as a perfect example of how Westminster incarnated the 'old boys' club' which, on top of excluding women, would not listen to, or could not hear, voices from outside the political Establishment. In the words of Green party member, Dr David McQueen: “...the poster campaign of 19th January clearly touched a nerve amongst broadcasters and political opponents with the smiling faces of Lucas and Bennett used to mock the 'old boy's (sic) club of Westminster". ${ }^{20}$

The second factor which, paradoxically, contributed to the Greens' inclusion in the TV debates was the decision of the Prime Minister, D. Cameron, to support them in this matter. That is, on $10^{\text {th }}$ January, the PM declared that it was unfair to exclude the Greens if UKIP were included. This concern for political fairness on the part of the PM could be seen in two ways. Firstly, it was part of a long British, cultural tradition of supporting the underdog, that is the person or group that is seen as getting a raw deal. Secondly, and more cynically, it could be greeted, and indeed was greeted, with a certain amount of scepticism by political commentators such as Nick Robinson (BBC) who considered that the Conservative Party leader was using the Greens as a stick to beat the Labour Party with. He quoted the PM's "private view" as being that "... if we, the Conservatives, are to get hurt by the people to our right, UKIP, then Labour and the Liberal Democrats should get hurt by people to their left, the Green Party". ${ }^{21}$

The opposition leader, Ed Miliband, believed that the PM was: "chickening out" while Nigel Farage (UKIP) was of the opinion that D. Cameron was “...using the Greens 'as an excuse' not to have a debate with UKIP...". ${ }^{22}$

As for the Greens themselves, reaction differed; from the cautious comment of Natalie Bennett: 
Obviously David Cameron has his own political interests but I think we should give the Prime Minister credit for recognising that the debates would be unbalanced and bad for British democracy if Ukip is included and the Green party excluded. ${ }^{23}$

to the undisguised elation of Green Baroness Jenny Jones of Moulsecoomb:

Ofcom's decision to deny the Greens "major party" status, she says, represented "pure delight, as far as we're concerned. They made us the story, and it enraged people." The Tories have also been helpful. "Dear old Cameron, God bless his cotton socks, said we should be in the debates, and put all the Tory bloggers - and the Sun - on our side! It's made all the difference for us." ${ }^{24}$

So, be it in terms of new party members, the increased number of Green candidates, the polling figures or the publicity gained from the TV debate, the political profile of the GPEW in the months running up to the election was higher than expected and raised hopes as to the election result. What political analysis can be drawn from this?

\section{Politics}

Initially, as in previous electoral campaigns, the Greens were seen by many political actors and commentators as an irrelevance. This time, however, the situation was different, with a political landscape that was already very different from the previous general election campaign. Since 2010, the majority party system had been weakened by the continuing rise of 'minority parties', the effect of which was to contribute to a form of fragmentation of the traditional, bipartisan British party system in the eyes of the public. This sense of political fragmentation had been reinforced with the formation of a coalition government in 2010 and continued with the rise of UKIP and the SNP, both of which were platforms for an anti-Westminster Establishment discourse. ${ }^{25}$ Whatever the reasons, the rise of UKIP had been impressive. In 2014, the party entered Parliament by winning two by-elections, in Clacton and Rochester and Strood, polling $60 \%$ and $39 \%$ of the vote, respectively. ${ }^{26}$ In European elections, the party went from $16.5 \%$ of the vote in 2009 to $27.5 \%$ in 2014 and in the two most recent local elections it had taken 139 from a possible 147 seats contested in 2013 and 163 from a possible 169 seats in 2014. In Scotland, the SNP was doing similarly well, especially since the Scottish referendum of September 2014. ${ }^{27}$ The loss of the independence referendum had clearly boosted the SNP's popularity and on the eve of the general election it was set to take fifty seats or more. Both of these minor parties were direct threats to all three of the major parties, UKIP to the Conservatives in particular and the SNP to Labour.

In this second part, we shall analyse the political ramifications of this backdrop to Green expectations. What electoral danger did the Greens represent and what appeal did they have for the voters?

\section{Green threat}

The arrival of the Greens onto this 'minorities' political stage went, at first, unnoticed. Traditionally, the Liberal Democrats have the best record on the environment ${ }^{28}$ and would, therefore, have been the first party to feel threatened by a resurgent Green Party. And feel it they did as many of their members were defecting to the Greens due to disappointment with their participation in the coalition government. By the beginning of October 2014, the GPEW estimated that around 50\% of their new members were disappointed Liberal Democrats ${ }^{29}$ and studies before the election revealed that a similar 
percentage of ex-Liberal Democrat voters of 2010 were intending to vote Green in 2015. ${ }^{30}$ However, the Liberal Democrats were not the only party to wake up to the Green threat in October 2014. The Labour Party also realised that their own vote was under threat and reacted by creating a Green Party Strategy Unit (GPSU) headed by a prominent Labour politician, Sadiq Kahn (shadow Justice Secretary), who was "given the job of heading up Labour's anti-Green 'unit, and trying to hammer home the well-worn warning that "every vote for the Green Party only makes it one vote easier for the Conservatives to win the election." ${ }^{31}$

This fear that Green support would split the Labour vote was encapsulated by the slogan 'vote green, get blue' and one of the main strategies of this unit was to dissuade potential green voters from voting Green by questioning the Green Party's capacity to govern. This was done by pointing to the only experience of governing the Greens had which was in local politics, in the town of Brighton where they had controlled the local council since 2013. Brighton was the first majority Green council in the country and its performance was closely followed by supporters and opponents. In the light of the green surge, it was virtually inevitable that opponents would latch on to any difficulties the Greens were having there and this is exactly what the Labour Party did. On $28^{\text {th }}$ October, Lord Bassam of Brighton wrote an article in the New Statesman ${ }^{32}$ employing what the political columnist Adam Bienkov termed a "good cop, bad cop' strategy", that is an attempt to woo Green voters by stressing how left-wing the Labour party had become since 2010 while directly attacking the Green council in Brighton to demonstrate how incompetent it was. ${ }^{33}$ Two weeks later, Sadiq Khan visited Brighton and subsequently wrote an article in The Independent using a very similar approach to Lord Bassam; extolling Labour's left-wing credentials and attacking Brighton Greens.

These two similar articles (among others ${ }^{34}$ ) by high-profile Labour politicians seemed to have two aims. Firstly, to steer potential Green voters all over the country who were not members of the Green Party, away from voting Green. And, secondly, to re-gain both the parliamentary seat of Brighton, taken from the Labour Party by the Green Caroline Lucas in 2010, and the Brighton local council which was up for election on the same day. According to Adam Bienkov, the GPSU had limited success in that the numbers of voters supporting the Greens continued to rise after the unit's creation, be it nationally or, locally, in Brighton. As we saw in the first section of this article, the national green surge continued apace regardless of the GPSU's creation and locally, in Brighton, this also seemed to be the case. In June 2014, for example, Lord Ashcroft carried out a constituency poll in Brighton which showed the Greens and Labour virtually neck a neck with Labour ahead by one point; five months later, the Greens were ten points ahead of Labour. ${ }^{35}$ Clearly, the local difficulties the Greens experienced in Brighton were not affecting its national campaign to retain the parliamentary seat of their only MP.

When it became clear that attacking the Greens was not working, the New Statesman journalist, Anoosh Chakelian, suggested a different, social class based solution to Labour's dilemma: "As I have reported before, the best rhetoric Labour can use is to emphasise the costly, predominantly middle-class nature of the "green lifestyle". ${ }^{36}$ She quoted one of Ed Miliband's aides who claimed that: "We've found the best line of attack is to attack the Greens as an uppermiddle class lifestyle choice". ${ }^{37}$

There were several reasons why the Labour Party was unable to stem the green tide but they seemed unrelated to weaknesses displayed by the Greens. Firstly, criticism of the Green council's performance in Brighton, as we have seen, did little to deter people from promising to vote Green. Secondly, the aforementioned poor media performance of the 
Green Party leader N. Bennett could have been a major setback for the Greens but after a couple of days, the media storm seemed to have blown over. Indeed, according to Prof. Philip Cowley, for people who intended to vote Green, this slip-up by Natalie Bennett mattered little as Green supporters were more concerned "about sending a message about the sort of society" they wanted to live in rather than the details of specific policies. ${ }^{38} \mathrm{P}$. Cowley's remark could also explain why the severe criticism of Green policies from the Right $^{39}$ and the Left ${ }^{40}$ seemed to have little effect on the Green vote.

\section{Green attraction}

On the other hand, the reasons why potential Green voters were growing in numbers was a reflection of the numerous attractions the Greens represented to a variety of sociopolitical groupings:

The Greens were in a new political position, given the Liberal Democrats' decision to participate in the coalition government of 2010. By doing so, the Liberal Democrats lost their place as the protest party they had long held within the British political system. Moreover, subsequently, they lost a lot of credibility with their supporters when they made a complete U-turn on the question of raising university fees in 2010 having sworn to oppose this rise during the electoral campaign of that year. Many of those supporters who could not bring themselves to supporting the Labour Party, now saw the Green Party as the best replacement.

Alongside the disappointed Liberal Democrat supporters stood the alienated supporters from the Blair-Brown days of New Labour who did not see Ed Miliband as a particularly radical change. This alienated, Labour left-wing felt much more in tune with the antiausterity discourse of the Greens which was the only party to take this stance in the campaign. In addition, many of the Green Manifesto policies ${ }^{41}$ appealed to this group, such as "Bringing the railways into public hands", ending the drive to "NHS privatisation", raising the minimum wage to $£ 10$ by 2020 , abolishing zero hour contracts and introducing "a wealth tax of $2 \%$ a year on the top 1\%". Further to the left of the Labour Party, many Green sympathisers, particularly young ones, saw in the Green Party, the British equivalent of the Greek (Syriza) and Spanish (Podemos) alternative Left which was also fighting austerity. Certain radical Green policies were also attractive to this group such as "cancelling Trident replacement and decommissioning existing nuclear forces and facilities" or reviewing "currently controlled drug classifications, within a legalised environment of drug use".

A further aspect of the Greens which appealed to critics of Establishment politics was the 'clean' image they had with regard to the MPs' expenses scandal in which they were not involved and the fact that their financing was seen as being above board with no large donations to cause them political embarrassment. Another, was the importance the Greens gave to gender equality. The Greens are the only party with a large majority of women in positions of power. On the Greens' website (section 'Our People'), two thirds of the official Green representatives mentioned are women: Parliament (House of Commons: Caroline Lucas; House of Lords: Baroness Jones of Moulsecoomb), Party (leader: Natalie Bennett; deputy leader: Amelia Womack), MEPs (Jean Lambert, Molly Scott Cato), London Assembly (Jenny Jones ${ }^{42}$ ). This prompted the Daily Telegraph reporter, Sophy Ridge, to declare "If there is a political glass ceiling, the Greens seem to have smashed straight through it". 43 
The Greens were also seen by many new supporters as the only party which held a resolutely anti-UKIP stance. Indeed, in an article of the Open Democracy website, Adam Ramsey stresses this stance as a reason why many people decided to join the Green Party:

One consistent message from new members is that they felt so horrified by the rise of UKIP that they had to do something. The sense that the Greens have been the only party standing up to UKIP rather than pandering to them seems to have attracted many to the party. A case in point here is the surge in Green membership around the Rochester and Strood by-election, where the party ran with the slogan "say no to racism". ${ }^{44}$

Clearly, the Greens had an attraction for different reasons but how far did this translate into results and where could these results lead them?

\section{Work in Progress?}

The vote count for the Greens was their best ever result, despite being well below what pre-electoral polls had suggested. In the UK as a whole, the Greens received $3.8 \%$ of the national vote and, although this almost quadrupled their share of the 2010 vote it was a far cry from the Ashcroft poll that put them on 11\% of voting intentions in January 2015. In the seats they contested, their average vote more than doubled.

Table 3: Green Parties (UK): General Election Results (2010-2015) ${ }^{45}$

\begin{tabular}{|l|l|l|l|}
\hline Year & Total Votes & Vote share (UK) & Average vote share (seats contested) \\
\hline 2010 & 285,612 & $1 \%$ & $1.9 \%$ \\
\hline 2015 & $1,157,630$ & $3.8 \%$ & $4.2 \%$ \\
\hline
\end{tabular}

If we consider the individual results of the three Green Parties in the UK (Table 4) over the same period, we can see that each one increased its score in 2015, with the GPEW quadrupling its national share of the vote.

Table 4: Green Party: Regional Results (2010-2015) ${ }^{46}$

\begin{tabular}{|l|l|l|l|l|}
\hline \multicolumn{4}{|l|}{ England and Wales } \\
\hline Year & Total Votes & Vote share & Average vote share (seats contested) \\
\hline 2010 & 265,243 & $1 \%$ & $1.2 \%$ \\
\hline 2015 & $1,111,603$ & $4.1 \%$ & $4.3 \%$ \\
\hline Scotland & \multicolumn{4}{|l|}{} \\
\hline Year & Total Votes & Vote share & Average vote share (seats contested) \\
\hline 2010 & 16,827 & $0.7 \%$ & $2 \%$ \\
\hline 2015 & 39,205 & 1.3 & $2.6 \%$ \\
\hline Northern Ireland & & \\
\hline Year & Total Votes & Vote share & Average vote share (seats contested) \\
\hline 2010 & 3,542 & $0.5 \%$ & $2.5 \%$ \\
\hline 2015 & 6,822 & $1 \%$ & $3.49 \%$ \\
\hline
\end{tabular}


This increased vote was seen by the Greens as an encouragement, as was the number of deposits saved. Up to 2001, they had never saved a deposit and this time, they saved 131 of them (Table 5).

Table 5: Green Party (UK) Electoral Deposits, 2001-2015

\begin{tabular}{|l|l|}
\hline General & Deposits saved \\
\hline $1974(\mathrm{Feb})$ & 0 \\
\hline 1983 & 0 \\
\hline 1992 & 0 \\
\hline 1997 & 0 \\
\hline 2001 & 10 \\
\hline 2010 & 7 \\
\hline 2015 & 131 \\
\hline
\end{tabular}

Before the elections, the Greens had laid out their ambitions by targeting 12 priority constituencies (Table 6) and, although they didn't reach expectations in winning any more seats, the increase in the vote was encouraging in places like Bristol West, Holborn and St Pancras (where the Party leader stood), and Sheffield Central. The surprise came in Norwich South which had a good score (13.9\%) but a marginally lower one (-1\%) than in 2010. However, this constituency was one of only two UK constituencies with a Green candidate in which the Green score did not increase. ${ }^{48}$

Table 6 : Green Targets $2015^{49}$

\begin{tabular}{|l|l|l|l|l|}
\hline Constituency 2015 (GPEW) & Candidate Greens & Total votes & Share votes\% & Change since 2010 \\
\hline Brighton Pavilion & C. Lucas & 22,871 & 41.8 & +10.5 \\
\hline Bristol West & D. Hall & 17,227 & 26.8 & +23 \\
\hline Cambridge & R.Read & 4,109 & 7.9 & +0.3 \\
\hline Holborn and St Pancras & N.Bennett & 7,013 & 12,8 & +10.1 \\
\hline Liverpool Riverside & M.Dobson & 5,372 & 12.1 & +8.6 \\
\hline Norwich South & L.Grahame & 6,749 & 13.9 & -1 \\
\hline Oxford East & A. Duncan & 5,890 & 11.6 & $+9,2$ \\
\hline Reading East & R.White & 3,214 & 6.4 & +4.2 \\
\hline Sheffield Central & J. Creasy & 6,999 & 15.8 & +12.1 \\
\hline Solihull & H. Allen & 1,632 & 3 & +3 \\
\hline St Ives & T. Andrewes & 3,051 & 6.3 & +3.5 \\
\hline York Central & J. Tyler & 4,791 & 10 & +6.5 \\
\hline
\end{tabular}

Where does this leave the Greens? The first answer is that the results left them very frustrated, on comparing their $3.8 \%$ of the popular vote with the $4.7 \%$ of the SNP and 
seeing that they ended up with one parliamentary seat to the SNP's fifty-six. Indeed, one of their first reactions was to join with the two other minority parties which participated in the TV debates (UKIP and Plaid Cymru) to protest against this further example of the 'First Past The Post' electoral distortions. The green activist, Peter Tatchell, also put his finger on this weakness of the British electoral system: "The Conservative Party secured 37 per cent of the votes cast but gained 51 per cent of the seats. Given the voter turnout of 66 per cent, this means they won the support of a mere 24 percent of registered electors". ${ }^{50}$

However, despite this dubious electoral backdrop, the performance of the Greens can also be seen as 'work in progress' when looking at the bigger political picture.

The first encouraging sign is that they managed to translate pre-election polls into actual votes much more efficiently than in previous campaigns. This is, of course, a reflection of the membership surge but also of the changing perception people seemed to have of them in terms of their capacity to take a share in government. On his political blog in January 2015, Adam Bienkov illustrated this point by referring to a YouGov poll in which more people chose the Greens than any of the four minority parties (SNP/Greens/UKIP/ Liberal Democrats) to take part in a coalition government. ${ }^{51}$

The second factor can be seen in the validation of the long term strategy the Greens adopted in the 1990s. In 1993, following a long period of internal conflict, the GPEW adopted a reform entitled 'Basis for Renewal' which was a form of compromise between those members who preferred to focus on social movement-type activism ('decentralists') and those who believed that the Greens needed to enter the political system by taking elections more seriously ('electoralists'). ${ }^{22}$ This compromise was built around the idea that, as in other European Green Parties, the British Greens would attempt to do both, by keeping a foot in both the political system and civil society. This strategy would involve being present in local activism (e.g. anti-fracking campaigns) and extending Green policy beyond its traditional environmental concerns to include social issues. It is a strategy which had already borne fruit in 2010, with the election of Caroline Lucas and the $1.2 \mathrm{~m}$ votes of this 2015 election could be seen as an extension of this. The Green Manifesto blends social (A Decent Livelihood: A one Planet Economy, Equalities, Health and Well-Being, A Place to Learn: Education, A Place to Live: Housing) and environmental issues (Earth, Energy and the Climate)..$^{53}$

A third factor is the progress of an alternative, green political culture which is a fundamental dimension of green philosophy. That is, the Greens believe that gaining political power is meaningless without a corresponding change in socio-cultural behaviour. In many ways, this is a corollary of the 'Basis for Renewal' compromise between grass roots activism and the formal political activity of seeking electoral representation and the dilemma for the Greens has always been to reconcile these two aims. The book that Caroline Lucas recently published ${ }^{54}$ illustrates these dual Green concerns and her actions inside Westminster (e.g. wearing an anti-sexist T-shirt in the House of Commons as part of campaign against page 3 of The Sun) as well as outside (e.g. taking an active part in the anti-fracking protest at Balcombe) reflect this Green need to reconcile words and deeds.

\section{Conclusion}

In reply to the question of our title, there was clearly a green surge before the election in different respects (membership, polls, etc.), the result of which was a quadrupling of the 
national Green vote. Given the electoral system, this did not produce any more seats but it did produce more confidence within the UK Green parties. Are the Greens still a case of 'work in progress'? No doubt, yes; that is, they need to convince many more people to vote for them before any share of national political power can be envisaged. One MP can hardly be seen as work done. There is, however, a more encouraging side to the idea of 'work in progress' whereby the strides that were made during the electoral campaign have consolidated UK Green party structures while also vindicating the 'Town Hall to Westminster'55 strategy that came out of the 1990s reforms.

The immediate task for the Greens is to retain all the support they have received in the last year. In the aftermath of the 1989 success, they were unable to do this and membership soon fell. This time, their political experience and organisation seem stronger but the challenge they face is sizeable given that the majority of their voters came from other political families. According to an Ashcroft poll (Chart 5) held on $7^{\text {th }}$ May, half of the Green votes came from ex-Liberal Democrats (50\%) with almost as many exLabour voters (18\%) as 'loyal' Green voters (19\%).

Chart 4: Who voted for the Greens? ${ }^{56}$

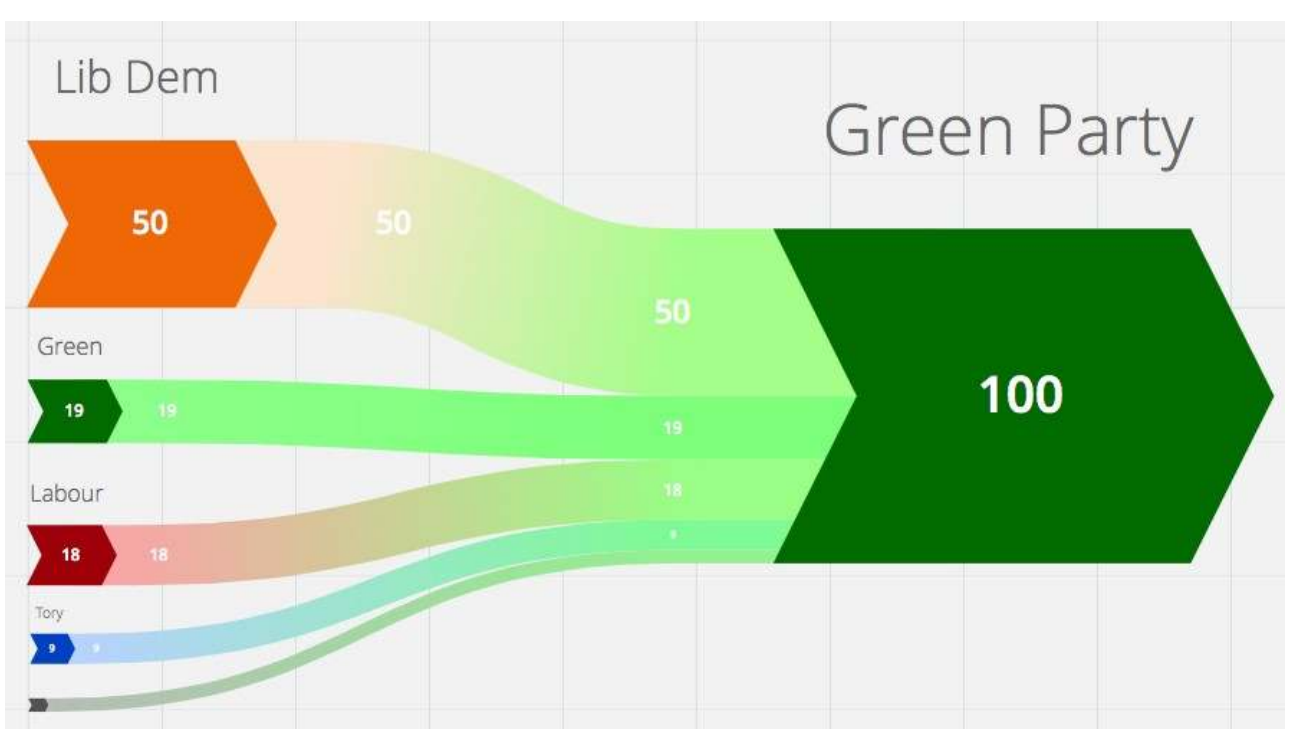

The post-election British political landscape is one in which five parties could challenge for a share of power in the next election. It is a landscape which has all the appearances of a multi-party system stuck in a two-party system straightjacket and during the course of this Parliament, this could produce different outcomes. From the position of the minority parties, it may be an opportunity to reintroduce the issue of proportional representation onto the political agenda. However, from that of the weakened Labour and Liberal Democrat parties, it could also raise the possibility of a centre-left realignment. The latter scenario reinforces the need for the Greens to embed their newfound supporters as soon as possible. 


\section{BIBLIOGRAPHY}

BIRCH, Sarah. "Real Progress: Prospects for Green Party Support in Britain", Parliamentary Affairs, 2008, 62(1), pp. 53-71.

BURCHELL, Jon. The Evolution of Green Politics. London: Earthscan, 2002.

CARTER, Neil. “The Green Party: Emerging from the Political Wilderness?”, British Politics, vol. 3, n ०2, 2008, pp. 223- 240.

GREEN PARTY, "For the Common Good", General Election Manifesto, 2015.

LOWE, P. \& GOYDER, J. Environmental Groups in Politics. London: George Allen and Unwin, 1983,

LUCAS, Caroline. Honourable Friends. London: Portobello Books Ltd, 2015.

PRENDIVILLE, Brendan. “British Environmentalism: a party in movement?”, The UK's Political Landscape in the 21st Century: Players, Strategies, Achievements, Revue LISA/LISA e-journal, XII-n ${ }^{\circ} 8$, 2014.

PRENDIVILLE, Brendan. "UK General Elections 2010: The Environment”, Revue Française de Civilisation Britannique, vol. 16, $\mathrm{n}^{\circ}$ 1, Presses de la Sorbonne Nouvelle, 2011.

YOUNG, Stephen. The Politics of the Environment. Manchester: Baseline Books, 1993.

\section{NOTES}

1. There are three Green parties in the UK: the Green Party of England and Wales (GPEW), the Green Party in Scotland, often called the Scottish Greens, and the Green Party in Northern Ireland. Unless otherwise stated, in this article, the Greens (or Green Party) refers to the Green Party of England and Wales.

2. Edward Goldsmith was founder of The Ecologist magazine in 1970 and instrumental in the founding of the Green Party, then called 'People', in 1973 (Brendan PRENDIVILLE, "British Environmentalism: a party in movement?" in David HAIGRON (ed.), The UK's Political Landscape in the 21st Century: Players, Strategies, Achievements, Revue LISA/LISA e-journal, XII-n ${ }^{\circ} 8,2014$ ). He was also an important financial backer of the party during difficult times.

3. Subsequently, in 2013, the Labour Party lost its majority on the local Brighton council to the Green Party and according to Rob Shepherd (Green Party media officer), "a running battle began between the two parties. In the local elections of 2015, Labour regained its majority on the council" ("How the Green Party is responding to Labour's fear of a "Ukip of the left"”, New Statesman, 17 November 2014, http://www.newstatesman.com/politics/2014/11/how-green-party-respondinglabours-fear-ukip-left (accessed 7.7.2015).

4. "Incredibly Awkward Interview With Natalie Bennett", LBC Radio, 24 February 2014, http:// www.lbc.co.uk/incredibly-awkward-interview-with-natalie-bennett-105384

5. Ed West, "Welcome to the completely bonkers world of the Green Party manifesto", The Spectator, 21 January 2015, http://blogs.spectator.co.uk/coffeehouse/2015/01/welcome-to-thebonkers-world-of-the-green-party-manifesto/ (accessed 7.7.2015).

6. Stephen YOUNG, The Politics of the Environment, Manchester: Baseline Books, 1993, p.37. 
7. Alex Hunt, "UKIP: The story of the UK Independence Party's rise", BBC News website, 21 November 2014, http://www.bbc.com/news/uk-politics-21614073 (accessed 7.7.2015); Tim Wigmore, "The rise of the "anti-Ukip" party: how the Greens are hammering Labour", New Statesman, 7 January 2015, http://www.newstatesman.com/politics/2015/01/rise-anti-ukipparty-how-greens-are-hammering-labour (accessed 7.7.2015); Frances Perraudin, "Lib Dem membership figures up 10,000 since general election", The Guardian, 13 May 2015, http:// www.theguardian.com/politics/2015/may/13/lib-dem-membership-figures-up-10000-sincegeneral-election (accessed 7/7/15).

8. This position is strengthened if we add the 400 members (2015) of the Green Party of Northern Ireland (Steven Agnew, “Greens' growth has just begun”, Belfast Telegraph, 3 March 2015, http:// www.belfasttelegraph.co.uk/opinion/debateni/steven-agnew/greens-growth-has-just-

begun-31105781.html (accessed 9.7.2015).

9. According to Frances Perraudin, "around 4,000" people joined the GPEW in the week following the General Election (The Guardian, op.cit.). By way of comparison, the French Greens (Europe Ecologie Les Verts/EELV) had 9,300 members in 2015 (Eric Dupin, "Le grand ratage des écologistes français", Le Monde Diplomatic, Avril 2015, http://www.http://www.mondediplomatique.fr/2015/04/DUPIN/52853 (accessed 20.11.2015).

10. http://www.ukpolitical.info/Donations.htm (accessed 9/7/15)

11. Ibid.

12. In a similar way to the New Zealand Greens ("Greens crowd-source proposed internet law", 3News, 23 April 2014, http://www.3news.co.nz/politics/greens-crowdsource-proposed-internetlaw-2014042312\#axzz3i1IplwXW, (accessed 9/7/15), the GPEW also used social media to crowd source funds in order to finance prospective candidates (http://www.crowdfunder.co.uk/greenparty-in-your-seat, accessed 9/7/15). One particular example of this was in Brixton (Jason Cobb, brixton "Green Party launches crowd funding campaign to help pay for leaflets in Streatham constituency", Brixtonbuzz, 7 January 2015, http://www.brixtonbuzz.com/2015/01/green-partylaunches-crowd-funding-campaign-to-help-pay-for-leaflets-in-streatham-constituency/;

accessed 9.7.2015).

13. Neil CARTER, "The Green Party: Emerging from the Political Wilderness?", British Politics, Vol. 3, No. 2, 2008, pp. 223-240.; http://www.electoralcommission.org.uk/our-work/our-research/ electoral-data?; accessed 30/7/15). In 1974, five candidates stood in the February election and four in the October election. The rise in 1992 could be partly explained by the confidence generated by the 1989 European Election result.

14. https://yougov.fr/, accessed 9/7/15.

15. http://lordashcroftpolls.com/2015/01/ashcroft-national-poll-con-29-lab-28-lib-dem-9ukip-15-green-11/ (accessed 9/7/15).

16. http://www.buzzfeed.com/jamieross/young-people-are-abandoning-labour-for-thegreens\#.rq7W2dExWK (accessed 9/7/15).

17. The British communications regulator.

18. http://media.ofcom.org.uk/news/2015/major-parties-consultation/ (accessed 9/7/15).

19. http://www.crowdfunder.co.uk/green-party-in-your-seat (accessed 9/7/15)

20. http://www.electionanalysis.uk/uk-election-analysis-2015/political-communication-andimage-management/did-the-green-surge-make-any-difference/ (accessed 9/7/15).

21. http://www.bbc.com/news/uk-politics-30726499 (accessed 9/7/15).

22. Ibid.

23. Anoosh Chaelian, "David Cameron refuses to appear in television debates unless the Greens are included", New Statesman, 8 January 2015, http://www.newstatesman.com/politics/2015/01/ david-cameron-refuses-appear-television-debates-unless-greens-are-included (accessed 9.7.2015). 
24. John Harris, "The Green surge: is this the party that will decide the election?", The Guardian, 21 January 2015, http://www.theguardian.com/politics/2015/jan/21/green-surge-party-thatwill-decide-election (accessed 9.7.2015).

25. This anti-Establishment discourse had been particularly prevalent since the MP expenses scandal which began in 2009.

26. http://www.bbc.com/news/uk-politics-21614073 (accessed 9/7/15). During the 2010-2015 parliament, the membership figures of UKIP more than doubled, rising from 17,184 in 2011 (ibid.) to 41,514 in 2015 (Matthew Holehouse, "Greens now have 'more members than Ukip' ", The Telegraph, 15 January 2015, http://www.telegraph.co.uk/news/politics/green-party/11347050/ Greens-now-have-more-members-than-Ukip.html (accessed 9.7.2015).

27. John Curtice, "Survation Add To Labour's Woes", What Scotland Thinks, 18 November 2014, http://blog.whatscotlandthinks.org/2014/11/survation-add-labours-woes/ (accessed 9.7.2015).

28. Brendan PRENDIVILLE, "UK General Elections 2010: The Environment », Revue Française de Civilisation Britannique, vol. 16, $\mathrm{n}^{\circ}$ 1, Presses de la Sorbonne Nouvelle.

29. Ben Riley-Smith, "Liberal Democrat conference: Seven reasons why the 2015 general election will be a five-horse race", The Telegraph, 6 October 2014, http://www.telegraph.co.uk/news/ politics/liberaldemocrats/11138579/Liberal-Democrat-conference-Seven-reasons-why-the-2015general-election-will-be-a-five-horse-race.html (accessed 9.7.2015).

30. James Dennison, "Green Party voters look like Lib Dems, think like Labour voters and are as dissatisfied as "Kippers", New Statesman, 17 February 2015, http://blogs.lse.ac.uk/politicsandpolicy/green-partyvoters-environmentalists-socialists-or-protest-voters/ (accessed 9.7.2015).

31. John Harris, "The Green surge: is this the party that will decide the election?", The Guardian, 21 January 2015, http://www.theguardian.com/politics/2015/jan/21/green-surge-party-thatwill-decide-election (accessed 9.7.2015).

32. Steve Bassam, "The difference between radicalism set in reality, and the Green Party", New Statesman, 28 October, 2004, http://www.newstatesman.com/politics/2014/10/differencebetween-radicalism-set-reality-and-green-party (accessed 13/7/15). Lord Bassam (Labour) was the leader of Brighton Council between 1987-1999.

33. Rob Shepherd ("Green Party media officer and a Green candidate for Preston Park, Brighton, in the 2015 council elections") replied to Lord Bassam's criticism of the Green council a couple of weeks later ("How the Green Party is responding to Labour's fear of a "Ukip of the left"”, "New Statesman, 17 November 2014, http://www.newstatesman.com/politics/2014/11/how-greenparty-responding-labours-fear-ukip-left (accessed 13.7.2015).

34. One article by Luke Akeshurt even made the claim that "the Greens are not a welcome addition to the UK's political spectrum" "We must not make the same mistake with the Greens that we did with the Lib Dems", LabourList, 28 October 2014, http://labourlist.org/2014/10/we-must-notmake-the-same-mistake-with-the-greens-that-we-did-with-the-lib-dems/ (accessed 13.7.2015).

35. Adam Bienkov, "Labour are losing votes to the Greens and they don't know why", Politics.co.uk , 19 December 2014, http://www.politics.co.uk/blogs/2014/12/19/labour-are-losing-votes-tothe-greens-and-they-don-t-know-wh (accessed 13.7.2015).

36. Anoosh Chaelian, "Why Labour can't counter the Greens' popularity with green policies", New Statesman, 16 January 2015, http://www.newstatesman.com/politics/2015/01/why-labour-cantcounter-greens-popularity-green-policies (accessed 13.7.2015).

37. Interestingly, this line of argument is reminiscent of the 1960 s Labour politician \& theorist, Anthony Crosland, who referred to "parts of the conservationist lobby" as having an approach which was "indifferent to the needs of ordinary people...(reflecting)...a set of middle and upper class value judgments (and wishing) "to kick the ladder down behind them" (Anthony CROSLAND, A social democratic Britain, London: Fabian Society, 1971, p.5).

38. http://blogs.spectator.co.uk/coffeehouse/2015/02/whats-more-important-to-voterscoherent-policy-or-the-chance-to-send-a-message/ (accessed 14/7/15). 
39. Matthew Holehouse, "Drugs, brothels, al-Qaeda and the Beyonce tax: the Green Party plan for Britain", The Telegraph, 5 March 2015, http://www.telegraph.co.uk/news/politics/greenparty/11356354/Drugs-brothels-al-Qaeda-and-the-Beyonce-tax-the-Green-Party-plan-for-

Britain.html (accessed 14.7.2015).

40. Conor Pope, "The Greens are a joke, and Labour shouldn't be frightened of saying so", New Statesman, 22 January 2015, http://www.newstatesman.com/politics/2015/01/greens-are-jokeand-labour-shouldnt-be-frightened-saying-so (accessed 14.7.2015).

41. "For the Common Good", General Election Manifesto, Green Party, 2015 (https:// www.greenparty.org.uk/assets/files/manifesto/

Green_Party_2015_General_Election_Manifesto_Searchable.pdf (accessed 14/7/15) . All quotations in this paragraph are taken from the Green Party Manifesto.

42. Baroness Jones of Moulsecoomb and Jenny Jones are one and the same person.

43. Sophie Ridge, "Forget Ukip: why the Green Party could decide the election", The Telegraph, 1 December 2014, http://www.telegraph.co.uk/women/womens-politics/11264812/Forget-Ukipwhy-the-Green-Party-could-decide-the-election.html (accessed 14/7/15). Alongside this focus on gender equality inside the party, among the major parties: "The Green Party, led by Natalie Bennett, has the highest percentage of female candidates - 37.5\%" ( http://www.bbc.com/news/ election-2015-32378852, accessed 14.7.2015).

44. https://www.opendemocracy.net/ourkingdom/adam-ramsay/green-membership-overtakeslib-dems-and-ukip-here\%27s-13-reasons-why (accessed 14/7/15).

45. The Electoral Commission (http://www.electoralcommission.org.uk/our-work/our-research/ electoral-data?; accessed 30/7/15).

46. Ibid.

47. CARTER, op. cit.; http://www.electoralcommission.org.uk/our-work/our-research/electoraldata? (accessed 30/7/15).

48. The Greens put up 573 candidates in the 2015 UK elections. Apart from Norwich South, the other constituency score to fall was in Aldridge-Brownhills (-0.1\%).

49. http://www.bbc.com/news/politics/constituencies (accessed 14/7/15).

50. Peter Tatchell, "Whatever you think of Ukip or the Greens, our electoral system is robbing them", The Telegraph, 14 May 2015, http://www.telegraph.co.uk/news/general-election-2015/ politics-blog/11606354/Whatever-you-think-of-Ukip-or-the-Greens-our-electoral-system-isrobbing-them.html (accessed 17.7.2015).

51. The question was: "Imagine there was a hung parliament at the next election, with no single party having enough MPs to form a government by themselves. Thinking about the other similar parties, do you think it would be a good or a bad thing if the following parties held the "balance of power" that is, they had enough MPs to influence who ended up forming a government?" (http://www.politics.co.uk/ blogs/2015/01/19/why-labour-s-anti-green-strategy-isn-t-working, accessed 17/7/15)

52. Brendan PRENDIVILLE, 2014, op.cit.

53. The Greens would argue that both social and environmental themes are part and parcel of each other be it in the Manifesto chapters or in real life.

54. Caroline LUCAS, Honourable Friends, London: Portobello Books Ltd, 2015.

55. This slogan was coined at the time of 'Basis for Renewal' to illustrate the decision to build up solid local electoral bases around the country before attempting to enter Parliament.

56. Source: http://lordashcroftpolls.com/wp-content/uploads/2015/05/LORD-ASHCROFT-POLLSPost-vote-poll-summary1.pdf, accessed 19 July 2015. 


\section{ABSTRACTS}

The Green Party has come a long way since it began standing for election in 1974. In the 2010 General Election it won its first parliamentary seat (Caroline Lucas, Brighton Pavilion) \& this time, hopes were high of not only retaining that seat but also of gaining one, and possibly two others. These hopes were heightened by what the media termed the "Green Surge" in the year leading up to the election during which membership rose considerably, reflected in increasingly optimistic polling figures. The result didn't live up to expectations in terms of seats but a sizeable increase in the number of votes left the Greens optimistic for the future. This article will analyse the reasons for this Green Surge, the politics of it and the situation the British Greens find themselves in following the results.

Depuis sa première participation aux élections législatives de 1974, le Parti vert britannique a fait beaucoup de chemin. Lors du scrutin de 2010, Caroline Lucas l'a fait entrer au parlement en remportant la circonscription de Brighton Pavilion. Cinq ans plus tard, les militants espéraient conserver au moins ce siège et, peut-être, en gagner un, voire deux autres. Ces espoirs ont grandi au cours de l'année 2014 lorsque le nombre de nouveaux adhérents au Parti vert est monté en flèche, accompagné de sondages électoraux encourageants. Les médias ont alors parlé de " poussée verte ». Néanmoins, en termes de sièges, les résultats n'ont pas répondu aux attentes et Caroline Lucas reste toujours la seule élue à Westminster. Par contre, l'augmentation importante du nombre de voix accordées au Verts génère un certain optimisme pour l'avenir électoral du parti. Dans cet article, nous présenterons une analyse de cette poussée verte pré-électorale, les ramifications politiques qu'elle a engendrées et la situation du Parti vert au lendemain du vote.

\section{INDEX}

Mots-clés: Parti Vert, écologie politique, élections législatives, poussée verte, partis minoritaires, environnementalisme

Keywords: Green Party, political ecology, General Elections, Green Surge, minority parties, environmentalism.

\section{AUTHOR}

\section{BRENDAN PRENDIVILLE}

Université de Rennes 2 